\title{
In Favor of the Equality in the Higher Education: The Policies of the Universities in the Spanish Educational System
}

\author{
Trinidad Mentado Labao*, Laia Arias Solé \\ Department of Didactics and Educational Organization, University of Barcelona, Barcelona, Spain \\ *Corresponding author: trini.mentado@ub.edu
}

Received October 31, 2014; Revised November 13, 2014; Accepted November 24, 2014

\begin{abstract}
The Organic Law 3/2007, dated $22^{\text {nd }}$ of March, for the effective equality between women and men (LOI, Ley Orgánica de Igualdad) provided by the directive 2002/73/CE of the European Parliament and of the Council on gender equality, dated $23^{\text {rd }}$ of September 2002, forces public authorities to guarantee mainstream incorporation of the gender perspective in public policies and to preserve the acknowledgement of the role of women in cultural, historical and economical fields, responding to this national equality policy in Spain. Hence the Spanish Higher education institutions' regulation (Law 6/2001, dated $21^{\text {st }}$ of December, about Universities, (B.O.E., Boletín Oficial del Estado 24/12/2001), modified by the Organic Law 4/2007, dated $12^{\text {th }}$ of April, (B.O.E. 13/04/2007), considers the creation of Equality Bodies (12 $2^{\text {th }}$ additional provision). In this communication, we present a general overview of how the European Community and Spanish universities apply this principle of equality by means of different supporting bodies, units, commissions and observatories, as well as the foreseen actions. All of this, to understand the intentions, decisions, objectives and adopted measures by the public authorities regarding gender equality.
\end{abstract}

Keywords: gender, gender equality, university, Higher education, plans of equality

Cite This Article: Trinidad Mentado Labao, and Laia Arias Solé, "In Favor of the Equality in the Higher Education: The Policies of the Universities in the Spanish Educational System." American Journal of Educational Research, vol. 2, no. 11 (2014): 1104-1109. doi: 10.12691/education-2-11-17.

\section{Introduction}

The present communication arises from the progress made by the research group of the University of Barcelona in the inter-university framework Program for a policy of equality and social cohesion in Higher education (ALFA III, 2010-2013) EUAI -EuropeAid/129877/C/ACT/Multi ${ }^{1}$.

This framework program focused on equity and social relevance for social cohesion in Higher education Institutions, contemplates gender policies as a transversal issue. Once again, the necessity to ensure the compliance of equality of opportunities is highlighted, as reflected in the directives provided by the Organic Law 3/2007, dated $22^{\text {nd }}$ of March, for the effective equality between women and men (LOI) provided by the directive 2002/73/CE of the European Parliament and of the Council on gender equality, dated $23^{\text {rd }}$ of September 2002, which forces public authorities to guarantee mainstream incorporation of the gender perspective in public policies and to preserve the acknowledgement of the role of women in cultural, historical and economical fields.

This framework program is organized by diverse commissions, among them, the gender commission

${ }^{1}$ Work team University of Barcelona: Montané, Alejandra (coord.); Barrios, Maite; Mentado, Trinidad; Olivé, M. Carmen and Villarroya, Anna. coordinated from the University of Barcelona. It is the only transversal commission that works to implement a gender policy in every dimension of this program with the aim of overcoming discrimination processes for women and increasing the equality of opportunities. This commission allows us to influence all aspects concerning gender in Higher education, among other aspects, their objectives are:

- To meditate about the presence of women in our Universities and countries.

- To enhance the visibility of work and research concerning gender topics carried out in our universities.

- Foment investigation and joint discussions concerning gender issues.

- To enhance the visibility of educational actions concerning gender issues carried out in our universities.

- To enhance joint educational experiences in the field of gender studies.

The gender commission of this framework program is a space open to dialogue, reflection and knowledge production in the field of equity and gender. It develops projects and documents with the aim of voicing gender policies in Higher education Institutes, guaranteeing nonsexist language, the non-discrimination of women, safeguarding parity, as well as developing the necessary 
mechanisms to reveal existing inequalities between women and men and enhancing its identification and correction. Moreover, the investigation team works to analyze the situation of Higher education in Spain through the legislation, policies of equality and supporting bodies.

\section{Development}

\subsection{Purpose}

The purpose of this communication is to present a general overview of the existing situation in the Spanish universities that work in favor of women with the aim of making their similarities and differences visible, not only in the naming of such spaces, but also in the performed and programd actions that are carried out in each of them in order to enter into debate about policies of equality that are carried out by the University.

\subsection{Women in the Spanish Universities}

The commitment to gender policies in Spanish universities is due to a prolonged and intense process of struggle and social demands, which convey the political, cultural and feminist perspectives (in both senses, academic and collective subject or social movement). In the recent period since the beginning of democracy, with important precedents in the resistance to Franco's Regime and significant advances in the Second Spanish Republic which we cannot ignore, Spain has experienced a great quantitative and qualitative leap in favor of equality of opportunities and in overcoming all forms of discrimination based on sex. Without a doubt, universities have been and are a relevant agent in this process.

Fortunately, for a number of years now and by means of an international agreement, statistics disaggregated by gender have become common, which facilitates analysis from gender perspectives. Even though female representation in university panorama has experienced a spectacular change in the last years, the exiting data regarding the situation of women in science and university highlights the dimensions of discrimination and inequality when opting for professional promotion, thus concluding that the full incorporation of women into universities has not implied their promotion in the academic world.

Pérez-Sedeño’s studies, 1996; García de Cortázar \& García de León, 1997, highlight the incipient tendency of women entering university education, initiated in the course of the democratic period, which had not allowed the overcoming of important differences in branches of knowledge (especially in engineering and technology with a higher masculine presence), or in access to higher levels of education (doctorate), preface to the teaching and researching career.

The report “Académicas en cifras 2007” published by Unidad de Mujeres and Ciencia del Ministerio de Educación (Women and Science Unit of the Ministry of Education) aims to serve as a tool to apprehend the real situation of women in the Spanish university system. Women form the majority of graduates in public universities (60\% in 2005/2006), whilst the number of female professors does not reach $14 \%$.

Women form the majority of the student body, however, they are a minority occupying decision-making positions. It is well known that a larger presence of women has been associated with a larger dedication on their behalf to certain disciplines considered more "feminine" (humanities, social sciences and law) and have had a higher presence in the lower categories of the academic ladder (Montané and Beltrán, 2011).

The famous scissor graph shows two lines representing each of the sexes which counts and compares the quantity of students, doctorates, professors and lecturers. It is the best sample of the uneven situation that women face in universities. Personal and socio-cultural factors form the so-called academic "glass ceiling", the obstacles women experience in order to access executive, decision making and responsibility positions in the academic world.

The lack of real equality in employment of women in universities occurs at the same time as the Senate urges the Government to develop equality training contents in official university degree plans. On this topic, it is also necessary to remark that gender equality is essential for growth and competitiveness, as well as being a fundamental right. The legal and political measures coexist with a considerable inequality when it comes to promotion in the academic world.

Among the conclusions of the research carried out by the Consejo Superior de Investigaciones Científicas (CSIC) regarding the reports on female researchers exposes that "the presence of women in the main national research system is parallel to the presence/absence of women in universities: in some specialities, such as Science and Physical Technologies, women continue to be a minority, whilst in others, such as Food Science and Technology, the proportion of men and women is close to parity" (CSIC, 2007).

\subsection{Organisms and/or Specific Support Structures for Equality of Opportunities between Women and Men in the European Union}

Equality between men and women is one of the fundamental principles of Community law. From the creation of the European Economic Community in the Treaty of Rome (1957), the issue of equality of opportunities for women was incorporated in the $119^{\text {th }}$ article that establishes the principle that men and women should receive the same salary for the same work. From then on, during the seventies, the treaty was expanded introducing some modifications and extending its application to employment training programs and Social Security.

The entry into force of the Treaty of Amsterdam, on the $1^{\text {st }}$ of May 1999, sets a landmark in EU policies for equality. On the $25^{\text {th }}$ of November 1999, a general framework was established in favor of equal treatment in access to employment, training and professional promotion, as well as working conditions.

The European Institutions have created structures with specific responsibilities concerning equality. In 1995, the Commissioners for Equal Opportunities group was created in close contact with the European Parliament, the Advisory Committee on equal opportunities between women and men and with the European Lobby of Women (that serves as a link between women's organizations throughout Europe and the European Institutions that care for equality of opportunities). 
The incorporation and control of the legislation concerning equality, the application of action programs and the integration of the gender dimension in all community policies is carried out by the Equal Opportunities Unit of the General Directorate V (Employment, Labour Relations, Social Issues), whilst the Information Service on women of the General Directorate $\mathrm{X}$ (Information, Communication, Culture and AudioVisual Sector) works to spread information about community policies and actions among women and promotes the debate about these policies with European women. There is also an advisory committee at European level on equal opportunities between women and men, which gathers representatives from national organisms for equality and social actors at European level, that supervise and advise the European Commission in the field of developing European policies on gender equality.

The need to involve more women in attaining decisionmaking positions has been acknowledged as high priority by the European Union. In the following years, with the aim of advancing towards the equality of opportunities and treatment between both sexes and fighting against all gender-based discrimination the EU adopts measures and guidelines which are subsequently incorporated into all EU member countries' national legislation. Specifically, since 1986 Spain has been modifying most of its labour legislation to incorporate the community guidelines on gender equality.

Although the progress of equal treatment and opportunities has not had the same rhythm in all areas (gender, ethnic or racial origin, religion, beliefs or ideology, disability, age and sexual orientation), currently, the project of an Integral Law for equal treatment and against discrimination which would guarantee equality among people regardless of their age, race or ethnic group, sexual orientation, religion or belief, gender and disability is being assessed not only in the labour field but also in the access to goods and services.

The equal opportunities programs at European level carried out are:

- First Action Program of the European Communities (1982-1985) for the promotion of equal opportunities for women. It is a program of equality of opportunities, which aimed at revising the legislation, raising awareness and changing mentalities. It also introduced positive action proposals and revision measures on the tax regime. Regarding the private field, the necessity of a distribution of professional, family and social responsibility was proposed. It is a general program that does not include evaluation types or a specific budget.

- Second Community Program for the promotion of equal opportunities for women (1986-1990). It maintains the same tendencies but incorporates proposals for the agreement between social agents. As with the prior program, the main focus is on the labour market, social security and European competences, but widening the scope to educational measures and family conciliation. At the same time, the program integrates itself into the framework of Europe for Citizens, that is to say, into the proposal of political deepening of the European project. In addition, an evaluation procedure is also agreed upon.
- Third Community Action Program for equal opportunities between men and women (1991-1995). It maintains the same line of measures in the labour market, with others of social content. The incorporation of the presence of women is emphasized, that is to say, the revaluation of women's contribution to society. In this case, the program does not only clearly state monitoring and evaluation mechanisms, but also specifies financing. At the same time, it creates specific programs and social networks were created.

- Fourth Community Action Program for equal opportunities between men and women (1996-2000). It contemplates mainstreaming defined as the application of the gender dimension to all policies and actions of the EU and its Member States. A specific committee composed by the representatives of the Member States and chaired by the Commission representative is created.

- Fifth Community Action Program for equal opportunities between men and women (2001-2005). It specifies the complementarity of the program, its financing and its evaluation. The program's objectives are specified in annex 3 and consist of a large quantity of measures, decisions, proposals, recommendations and communications of European institutions.

The programs consist of a large quantity of measures, decisions, proposals, recommendations and communications of European institutions, and from them, we can extract the gender policy of the European Union. The evolution of gender policies in the last 30 years is visible, especially considering the commitment to social content, evaluation, consciousness raising about the need to economically support action proposals, the idea of mainstreaming, and above all, the commitment to the evaluation of the actions carried out during these years. This is precisely the link between all action programs; each of them proposes new ideas to improve the previous one.

\subsection{Organisms of equality in Spanish Universities}

As specified in the Plan for Equal Opportunities (20082011), Higher education has a series of commitments in favor of gender equality. In short, this plan takes into account Higher education in two of its axes; education and knowledge. Whilst in the axis related to education, the actions for gender equality in the higher level are gathered in a general manner, in the knowledge axis, actions are gathered in an explicit manner. The specific actions that make reference to Higher education are presented and classified below according to the axis in which they are included (education or knowledge):

- Axis of education:

- Promote the creation of Gender Studies Units, aimed at specific training, investigation and elaboration of didactic material in Education Faculties and Teacher Training Colleges.

- Promote the creation of postgraduate studies specialized in equality of opportunities between women and men in education, coeducation, non-sexist orientation and prevention of gender-based violence. 
- Create an action protocol for the prevention, detection, and action against gender-based violence in education centres, professional training centres and universities.

- Promote total care, psychological support, individual monitoring and advisory programs transitions such as the move from primary to secondary or university degrees and Professional Training.

- Develop action guides addressed to Universities and Professional Training Centers in order to make student information, recruitment and orientation campaigns influence in a specific, non-sexist and non-racist manner in professional orientation.

- Axis of knowledge:

- Support the development of specific Women's Studies. - Support the creation and consolidation of Seminars and Institutes of Women, Feminists and Gender Studies. - Promote the inclusion of the gender perspective in core subjects of degrees, especially in Social Sciences, Humanities and Health Sciences.

- Promote the presence of women in the investigation field.

- Strengthen the presence of women in the design, implementation and evaluation of investigation policies.

- Support the creation of women's associations regarding Science and Technology.

- Use of non-sexist language in all documents belonging to the National Plan of Research, Development and Innovation $(\mathrm{R}+\mathrm{D}+\mathrm{I})$.

- Promote the visibility of female researchers in the documents belonging to the National Plan of Research, Development and Innovation $(\mathrm{R}+\mathrm{D}+\mathrm{I})$.

- Highlight women's diversity and interests regarding innovation, especially in Biotechnology and Women's health.

- Promote participation of Spanish female researchers and technologists in International science and technology initiatives.

- Support the creation of a database of female scientists organised by their research field.

- Promote studies and research with gender perspective. - R+D+I statistics disaggregated by sex

- Analyze the possible assignation of a specific code to Women, Feminists and Gender Studies, inside UNESCO's nomenclature.

- Include the Strategic Action of Development for Equality of Opportunities between Women and Men in complementary summons of the National Plan R+D+I.

- Promote the implementation of the mainstreaming principle in the Spanish scientific and technological system.

- Support the development of studies about the presence of women in different University levels: faculty members, researchers, administrators and student body.

- Encourage the development of programs that make professional, personal and family life compatible with university life.

- Promote equalitarian development of women's presence in Governing Bodies of Universities.

- Support the creation of observatories and commissions for equality of opportunities in Universities.

- Promote the implementation of gender mainstreaming in university policies.
- Promote the appointment of women as Honorary Doctorates.

- Support the associations of female university students.

- Support the creation of a network of young women specialized in Women, Feminists and Gender Studies.

- Encourage the creation of a database of young female researchers.

By means of information provided by different Spanish universities, we can point out that there is little conformity in reference to the names of the different structures: in some cases, they are referred to as equality units, commissions, secretary's offices, offices and even observatories. In any case, they are bodies responsible for coordinating, proposing, monitoring and assessing the compliance of the legislation concerning equality between women and men, and of the plans and/or measures established by law and by universities for the promotion and achievement of effective equality in all aspects of university life.

38 public universities have been analyzed through their own websites with the objective of analyzing the level of visibility. In view of the fact that the law forces Spanish universities to have these organisms among their organizational structures, the majority of Spanish universities have started to work on the creation of these organisms. $^{2}$

For the network of Gender Equality Units for university excellence (RUIGEU) (2012), equality units are necessary among other reasons because it is essential to eliminate segregation in universities; vertical segregation (few women in high responsibility posts) and horizontal segregation (few women or few men in certain specialties); because a change in stereotypes and gender roles that influence concentration of men and women in certain studies, knowledge areas or services is needed; because it is necessary to take women into account in the language and contents of degrees; because according to the new Law of Science, Technology and Innovation, it is essential to incorporate the gender perspective into all research; because the achievements and scientific research on gender should be acknowledged and shared; because it is essential to reach a balanced representation of women and men in governing, research and management bodies; because the participation of governing and management bodies of universities is vital to develop equality based actions; because gender mainstreaming should be one of the guiding principles in all university activities (management, teaching and research) and because the principle of equality of treatment and opportunities between women and men should reign among all actions carried out by universities.

Martínez, C.; Lusa, A.; Calvet, M.; Gallego, I.; Pons, O. \& Tura, M. (2006) present a guide for the design and implementation of a plan of equality of opportunities in a public university, taking into account the stages of the proposed process for the design of a plan -phases, initiative, institutional commitment, commission creation,

\footnotetext{
${ }^{2}$ Even though at the time of the study it was not possible to find information concerning equality organisms in the following universities: University of Alcalá, University of Almería, University of Burgos, University of Córdoba, University of León, University Miguel Hernández, University of Murcia, University Nacional de Educación a Distancia(National Distance Education University), University of Oviedo, Polytechnic University of Valencia, Public University of Navarra, University Rey Juan Carlos y University of La Rioja.
} 
diagnosis, plan of action, diffusion, implementation and monitoring and evaluation.

\section{Conclusions about Equality Policies in Higher Education}

The gender policy assumes the concepts of gender mainstreaming and the equality of opportunities between women and men in Spain as a priority emanated from the European social policy. The creation of Equality Units at a national, regional and local level, developed programs, strategic plans effectively carried out, quality services and the cooperation of third parties are the key to develop the general principles that the law establishes and in turn respond to constitutional mandates.

Fortunately, in the last years and by international agreement, statistics disaggregated by gender become common, which facilitates the analysis from the gender perspective. The existing data about the situation of women in Science and University reveals the dimension of discrimination and inequality at times of professional promotion, concluding that the full incorporation of women into university life has not implied their promotion in the academic world, even though it is a fundamental right and gender equality is essential for growth and competitiveness.

As previously noted at the beginning of this communication, the Organic Law 3/2007, dated $22^{\text {nd }}$ of March, forces public authorities to guarantee mainstreaming in incorporation of the gender perspective in public policies and to preserve the acknowledgment of women in cultural, historical and economical fields. In this respect, Spanish universities are forced to obey this mandate without question and they begin to institutionalise support organisms to guarantee effective equality between women and men in Higher education.

An initial approximation to the analysis of organisms for equality in Higher education leads us to conclude that a great effort is being made in Spanish universities in order to organise structures, but the information is much disseminated.

Based on the information provided by different Spanish universities, it is possible to find units of equality, commissions, secretary offices, offices and even observatories. In any case, they are bodies responsible of coordinating, proposing, monitoring and evaluating the compliance of legislation of equality between women and men, and of the plans and/or measures that are proposed by law and by universities for the promotion and accomplishment of effective equality in all fields of university life.

This is a space created inside universities controlled by the vice-rectory and created by a commission that sets actions in motion through action plans, whilst the gender observatory is a platform generally destined to spread the situation of universities, their commitment and to raise awareness in the University Community.

The majority of such structures focus on diverse tasks: study and analysis of the situation of women in the university context, training, creation of activities of diffusion and consciousness, databases of women related documents, meetings, guides of good practices, resources, etc. In short, a wide range of actions that show that each university adopts and understands these structure in their own way.

In many cases, such as in the University of Valencia, Salamanca, La Laguna, etc., they have more than one structure for equality as well as an observatory. In the majority of them they also have an advisory commission that represents the whole University Community.

The majority of these equality organisms depend on the universities in which they are developed and are protected by the diverse vice-rectories, according to the structure of the universities in question. In this respect, we find that units of equality can be related to the Vice-rectory of students, Cooperation and Equality or Vice-rectories of Planning and Strategy of Quality or Vice-rectory of Institutional Relations and Communication, according to each case.

But in spite of the legal mandate that forces universities to have structures that safeguard gender equality, not all of them have effective equality plans ${ }^{3}$. Out of the 38 public universities analyzed through each of their websites, we can conclude that, 27 of them are developing the I Plan of equality between women and men; 2 public universities have set the II Plan of equality between women and men into motion; and 9 are still in the diagnosis stage.

Martínez, C.; Lusa, A.; Calvet, M.; Gallego, I.; Pons, O. \& Tura, M. (2006) present a guide for the design and implementation of a plan of equality of opportunities in public universities. We can state that some institutions are in the middle of the diagnosis of women's situation in the university, as it is the case of:

- University of Zaragoza with the Observatory for gender equality, of which the main objective for 2011 is the presentation and diffusion of the situation diagnosis in the University of Zaragoza and the elaboration of the I Plan of Equality.

- University of Las Palmas de Gran Canaria will create an indicator system with updated databases and statistics for the elaboration of the I Plan of Equality by means of the document Women and Men of the ULPGC (2010-2011).

- University of Castilla la Mancha where the Unit of Equality is working on the elaboration of the I Plan of Equality of opportunities between men and women.

In other cases, the I Strategic Plan is already functioning as in the case of:

- University of Huelva with the Unit of gender equality. They have a strategic plan to determine the situation of women in Universities and to encourage training, research and innovation.

- University of Sevilla, Unit for equality. I Plan for equality (2009-2012).

- University of Valladolid, among its objectives we find prioritizing the respectful education with equality of opportunities; facilitating the participation of women in the labour market; prioritizing the collaboration between universities and businesses to facilitate the incorporation of women to employment; establishing mechanisms of prevention and training

\footnotetext{
${ }^{3}$ Plan of Equality "organised combination of measures adopted after carrying out a situation diagnosis, designed to reach equality of treatment and opportunities between women and men and eliminate gender discrimination in businesses" (Organic Law for Effective Equality between Women and Men, Art. 46.1).
} 
and promoting joint responsibility in social, university and working life.

- University of Lleida, carried out a study on the situation of women with the help of the Catalan Institute of women and through the Dolors Piera Centre during 2005, it was aimed at the realisation of training activities or research works related to the field of competences of the Institute.

- University Pompeu Fabra, with the following axes of action: visualization and awareness-raising concerning gender inequalities; communication: work access and promotion in professional career; balanced representation of governing, advisory and decision-making bodies and conciliation of personal and working life.

- University Rovira i Virgili, through the Observatory, it develops the I Plan with the following axes of action: action and visibility of sexism; access to egalitarian working conditions and professional promotion; commitment with gender equity; promotion of the gender perspective in teaching and research and balanced representation in decisionmaking bodies.

- University of Santiago de Compostela, through the gender office sets into motion the I Strategic Plan of equal opportunities between women and men of the University of Santiago de Compostela (2009-2011), inspired by the three strategic principles: social responsibility, equal treatment and acknowledgment of maternity as social value.

- Autonomous University of Madrid through the Unit of Equality develops the I Plan of equality of the Autonomous University of Madrid (2011-2014). Its axes of action are aimed at: diagnosis, creation of equalitarian culture; equality at work; teaching, research and participation in governing and decisionmaking bodies.

- University of País Vasco through the Direction of Equality sets into motion the I Plan of equality of women and men of the UPV/EHU (2010-2013).

- University of Valencia with the I Plan of Equality (2010-2012) contemplates the following axes of action: diagnosis and visualization; communication and awareness-raising; labour issues; research and teaching and participation and governance.

Other Universities are already implementing the II or III Plan of Equality, as in the case of:

- University of Barcelona with the II Plan of equality of opportunities between women and men (20112013).

- Autonomous University of Barcelona with the III Plan of action for the equality between women and men (2013-2017).

Specifically and related to training, regulated training oriented to gender and equality of opportunities is offered in some Spanish universities, as in the case of:

- Autonomous University of Barcelona that offers a postgraduate degree in gender and equality (academic year 2011-2012) provided by the Department of Political Science and Public Law.
The University Complutense of Madrid offers an Official Master in Feminist Studies and the title of specialist 'Agent for the detection and total intervention in gender-based violence' at the Feminist Research Institute; an Official Master Doctorate Women and Health and some postgraduate studies on Gender and Social Sciences.

Finally, we understand that for these structures to have a real effect within the university institution, they should be directly promoted by the vice-rectory as stated in the manifesto presented by the Network of Units for Gender Equality for University Excellence (RUIGEU) dated $8^{\text {th }}$ of March 2012. Universities functioning under the perspective of real equality between women and men can reach academic quality and excellence. In this respect, the desired commitment of institutions should be aimed at changing the current situation and encouraging all universities to have units of equality and equality plans to enforce the Organic Law 3/2007 dated $22^{\text {nd }}$ of March on Effective Equality of Women and Men.

\section{References}

[1] European Commission. Dirección General de Empleo, Asuntos Sociales e Igualdad de Oportunidades (Unidad G1) (2008) Manual para la perspectiva de género en las políticas de empleo, de inclusión social y de protección social. Oficina de Publicaciones Oficiales de las Comunidades Europeas. Luxemburg.

[2] Informe “Académicas en cifras 2007”. Unidad de Mujeres y Ciencia del Ministerio de Educación. España: MUCD

[3] Organic Law 3/2007, dated $22^{\text {nd }}$ of March, para la igualdad efectiva entre mujeres y hombres.

[4] Organic Law 4/2007 dated 12 of April, que modifica la Ley de Universidades.

[5] Martínez, C., Lusa, A., Calvet, M.D., Gallego, I., Pons, O. y Tura, M (2006) Guía para el diseño y la implantación de un Plan de Igualdad en las universidades. Institut Català de les dones, Generalitat de Catalunya. X Congreso de Ingeniería de Organización, Valencia (España).

[6] Montané, A.; Beltrán, J. (2011). Miradas en movimiento. Textos y contextos de políticas de educación. Valencia:Germania.

[7] Pérez Sedeño, 1996; García de Cortázar y García De León, 1997.

[8] Consejo Superior de Investigaciones Científicas (CSIC) http://www.csic.es/web/guest/home;jsessionid=CD0A35069FC7E C22C665B72AD4E0E766.

[9] Delegación del Gobierno para la Violencia de Género http://www.migualdad.es/violencia-mujer/index.html.

[10] Instituto de la Mujer, http://www.migualdad.es/mujer/.

[11] Observatorio Estatal de Violencia sobre la Mujer, http://www.migualdad.es/violenciamujer/Index_Observatorio.html.

[12] Observatorio Jurídico-laboral de la Violencia de Género, http://www.olvg.uma.es.

[13] Red de Unidades de Igualdad de Género para la Excelencia Universitaria (RUIGEU) (2012)

http://www.unican.es/Vicerrectorados/difusion/unidaddeigualdad/ Red+Unidades+Igualdad+G\%C3\%A9nero+para+Excelencia+Uni versitaria+(RUIGEU).htm.

[14] Secretaría General de Políticas de Igualdad http://www.migualdad.es/igualdad/index.htm.

[15] Universidades españolas con Unidades de Igualdad. Fuente: Información extraída de la Universidad Carlos III de Madrid (información actualizada en el 2010): http://www.uc3m.es/portal/page/portal/organizacion/unidad_igual dad_uc3m/enlaces/unidadesigualdad_otras_universidadesespanolas.

[16] Unidad de Mujeres y Ciencia (UMYC).

[17] http://www.micinn.es/portal/site/MICINN/menuitem.7eeac5cd345 b4f34f09dfd1001432ea0/?vgnextoid=e218c5aa16493210 VgnVC M1000001d04140aRCRD. 